\title{
THE APPLICATION OF EFFECTIVE METHODS IN TEACHING ENGLISH IN PRIMARY SCHOOL
}

\author{
Narshabaeva Aliya Yumutbaevna \\ Senior Lecturer, Nukus state pedagogical institute named after Ajiniyaz
}

Article DOI: https://doi.org/10.36713/epra4611

\begin{abstract}
ANNOTATION
The report discusses the most effective methods of teaching English in primary school, the use of various new pedagogical technologies, poems, game elements, videos in teaching English. There are also methods of teaching phonetic and grammatical exercises, ICT and electronic textbooks, focusing on the system of exercises used to form phonetic skills, the effectiveness of the use of interactive methods in teaching a foreign language.

KEY WORDS: teaching English, primary school, games, songs, e-textbooks
\end{abstract}

\section{INTRODUCTION}

Crossing the threshold of the XXI century with the aim of developing education and science in the direction of innovative technologies is the main symbol of great hopes. It is said that the future of the educated generation is bright, and the main requirement of today is to educate the younger generation consciously, meaningfully and morally.

At a time when the country's relations with other countries are growing, our current task is to train people who are fluent in English and can use their knowledge in various fields in the future. Society needs to deepen and teach English. Becoming an independent country of the Republic of Kazakhstan and embarking on the path of world civilization requires a good command of the English language [6].

The purpose of teaching English at an early age is for students to master the basics of communication in English. Teaching English at an early age improves students' communicative development skills, stimulates students' interest, and allows them to speak more than one language at a time. And mastering English, which is informally established as a world language, strengthens the nation's competitiveness. Knowledge of modern
English is a matter of time. English is an important tool for interpersonal and intercultural communication, which allows us to develop international relations of our country [2].

The main task is to arouse students' interest in teaching English. There are many difficulties in learning a foreign language. To overcome these difficulties it is necessary to increase the enthusiasm for the subject.

To increase and stimulate students' creativity lessons can be conducted in the following ways:

1. Extensive use of visual aids in the classroom;

2. Modification of the lessons;

3. Use of posters, pictures, diagrams created by students in the lesson;

4. Effective use of modern technologies;

5. Utilizing videos and films related to the lesson;

To develop students' cognitive and communicative competences in English, it is important to use game elements during the lessons [1, p. 19].

Games allow performing important methodical tasks:

1. To make children psychologically ready for speech communication; 


\section{EPRA International Journal of Research and Development (IJRD) \\ Volume: 5 | Issue: 6 | June $2020 \quad$ - Peer Reviewed Journal}

2. To meet their natural need for more repetition of language material;

3. To train students to choose the right style of speech which is generally a preparation for the unexpected situations;

\section{RESPONSIBILITIES}

1. To study the literature on the use of game techniques as a means of stimulating the cognitive activity of adolescents in English lessons;

2. To analyze different approaches to the grouping of game techniques;

3. Teaching through games increases their interest in the subject, trains them to express their thoughts, opinions, views, listen to the response of another person, to supplement it, to tell about their achievements and shortcomings;

Music has a great influence on teaching English. New words and phrases are used as a means of language communication, which contributes to the growth of the student's vocabulary. Familiar vocabulary is quickly memorized by students while listening to songs and poems. Songs during the lesson should be carefully selected based on the students' age. E-textbooks are also very useful. Through the use of electronic textbooks in the classroom, students are trained to increase creativity, increase search, to form a cognitive outlook, to quickly perform independent work [3, p. 18].

The e-textbook contains experiments and the lives of the main characters, a reference dictionary, and test questions on each chapter. This information stimulates students' own search and skills to work in this direction.

With the use of modern information technology, it is possible to deepen interdisciplinary ties at all levels of the educational process. This increases the student's ability to think in terms of information and society. Education in this area inspires students to love their motherlands, friendship and cooperation.

It is necessary to use visual aids, technical aids more often to increase the cognitive activity of students, forming their learning and cognitive competencies [4, p. 25].

Here, after students receive any information or text, they have their own view of that information. That is, it leaves an emotional mark on a person's inner world, so the teacher creates a positive attitude to the information provided and lays the foundation for knowledge [5, p. 14].

Primary school is the basis of all knowledge. Any language can be mastered very quickly, as it is the age of real perception, which instills in the minds of primary school students what you teach. Nowadays, English language is the basis of our school, starting from kindergarten. If our children take a firm step on the language side, it will lay the foundation for them to take a bright path in the future.

Although the language skills of primary school students are not fully developed, of course, English is more difficult at first, but in the end it is possible to gradually develop and speak a smooth and beautiful foreign language. Since primary school students cannot carry heavy workloads, we often need to educate children in new ways so that they do not get demotivated to learn English.

The future of the country is in the hands of future generations, that is, they must be ambitious, morally-assured, disciplined, as well as welleducated. In addition to that, no matter where in the world it would be, should not they have the ability to showcase their power? How can an English language, which has become the language of the world today, not depend on this.

\section{REFERENCES}

1. Petrov A.V. Encourage activity through play activities. Moscow, 2001.

2. Kalmykova E.V. Teaching through game technology in primary school. Moscow, 2007. 3. Nurlanbekova E. Use of videos in foreign language teaching. Methods of teaching a foreign language. Almaty, 2005. №2. Pp. 17-18.

3. Utegulova Z.N. Methods of teaching a foreign language. Almaty, 2009. №4. Pp. 23-24.

4. Foreign language at school. Almaty, 2009. №52. Pp. 14-17.

5. Amandykova G.N., Mukhtarova Sh. E., Baimukanova B.S. Methods of teaching a foreign language. Almaty, 1992. Pp. 35-37. 